\title{
Res judicata of criminal judgement before the civil judge: $A$ comparative between Jordanian legislation and Syrian legislation
}

\begin{abstract}
Ebtesam Ahmed AL Mahmoud
Academic rank: Assistant Professor

Abstract

This research dealt with the claim preclusion " res judicata" of criminal judgement before the civil judge. As a comparative study between the Jordanian legislation and the Syrian legislation. It is known that penal legislation has decided the rule of res judicata against the civil case before the civil court. In the case of a civil case, a criminal judgment may be issued in the criminal proceedings, and the criminal judgment has res judicata that the civil court is obliged to respect it and not to judge contrary to final decision, whether the issued judgment was acquitted or the conviction as long as the civil action was not finalized. This study aims at discussing this subject in comparison between the Jordanian penal legislation and the Syrian penal legislation and to try to stand on the similarities and differences between them on this significant issue.
\end{abstract}

The researcher used the descriptive approach by extrapolating the texts governing the title of the study in the legislation which are the Syrian legislation and the Jordanian legislation. The researcher used the analytical method by using the logical analysis of the texts of the legislations in order to extract the rule of matters in which has no specific text, issues that are subject to ambiguity and disagreement through multiple jurisprudential readings and legislative texts. The study was divided into sections ; an introduction and two topics. The first topic: What is res judicata "claim preclusion"? The second topic: The implications of the res judicata of the criminal judgment before the civil judiciary.

The study reached many conclusions and recommendations, including: Authenticity is a kind of refrain enjoyed by the ruling, which is considered by virtue of including a presumption that does not accept the contrary decision in terms of its form and subject, it is the title of the truth, and the most important direct effects of res judicata before the civil judiciary is the following: It is not permissible to look into the issue of criminal judgment again before the civil court and it is not permissible to re-examine the subject of a complaint to give a check that does not receive a balance before the civil court after the criminal court decided by a final penalty.

Key words: Res judicata , criminal judgement, authenticity of criminal judgment

DOI: $10.7176 / \mathrm{JLPG} / 88-27$

Publication date: August 31st 2019

\section{Introduction}

Judicial judgment is the means by which the claimant acquires his civil rights and it is a way to issue the appropriate punishment against the offender in criminal proceedings. In ancient times, provisions have been subject to respect and sanctity that prevents the judge from reviewing the rights or decisions contained therein. Nowadays, the judiciary obliges the litigants, imposes laws and provide immunity from being void or change except in some subjects which are obtained from their sources .

Res judicata or as it is known claim preclusion is a kind of preclude enjoyed by the judgment, which is considered by virtue of including an evidence that does not accept another evidence to contrary in terms of form and subject, as it is the title of the truth.

Res judicata stands for the final judgement without the need to mention its facts or causes, although it can be the authoritative reason, when it is closely linked to the final decision so that the judgement cannot be understood if it is separated from the reasons.

Accordingly, the court which has rendered the judgment shall not review or amend the provision and other courts shall also refrain from considering the foregoing, unless these courts by law are the courts where the appeal shall be conducted before it.

It is well known that the criminal court is competent to hear criminal proceedings, resolve their cases, prove that the accused person committed the offense, determine and impose the penalty as it is the basis of the civil action according to the criminal claim, because the crime is the reason for the penalty and the civil harm resulting therefrom is the reason for compensation.If the person who has been affected by the crime, who did not wish to pursue the claim for compensation before the criminal court and was tempted to follow to the normal 
way of claiming his right before the civil court, the criminal legislation decided the rule of the authenticity of criminal judgment against the civil action before the civil court, In the case of hearing a civil claim, a criminal judgment may be issued in the criminal proceedings, and the criminal judgment has res judicata. Which implies that, the civil court is obliged to respect this decision and not to judge contrary to its final decision, whether the judgment was acquitted or convicted if the civil lawsuit was not confirmed .

This study discusses this important matter in comparison between the Jordanian penal legislation and Syrian penal legislation and try to identify the similarities as well as the difference between them.

\section{The importance of the study}

The importance of this study can be summarized as follows:

1. Its great importance for those who are interested in criminal case, as it clarifies and defines the termination of the criminal cases on a system of proper basis.

2. It is an important penal principle, which all criminal legislation has adopted, and which gives the victim of a crime the choice between the criminal and civil paths. Except the legislations that grant each judiciary the right to retain its own power and to retain at the same time their independency in decisions.

\section{The study problem}

The problem of the study lies on the need to determine the extent of the authenticity of the criminal judgments issued by the criminal courts and which meet the conditions of execution before the civil judge. Since many of these provisions include rights of the victim resulting from the commission of the crime and a judgment has been handed down therefore, it is necessary to prove the extent of authenticity of these penal provisions before a civil judge.

\section{The question of the study}

The main question in this study is limited only to explain the extent to which the criminal judgments issued by the criminal courts before the civil courts are authentic.

\section{Methodology of the study:}

The researcher relied on the descriptive approach through the extrapolation of the texts in the both legislations, Syrian legislation and Jordanian legislation. The researcher also used the analytical method using the logical analysis of the texts in order to extract the rule of matters in which there is no text or opinion or issues that are ambiguous and different through investigating multiple jurisprudence and legislative texts

\section{Previous Studies:}

There are many legal studies that dealt with the subject of this study and I will try to benefit from them for the purpose of preparing this study and to come up with new findings and conclusions in the matter of this study. The most important of these studies are:

A study entitled: The authenticity of the criminally imposed order on Civil, prepared by Sunnih AL Eish Malak, published by Dar Al-Attrash, Tunis.

-A study entitled: The authenticity of the criminal judgment before the civil judge, prepared by: Edward Ghali Al Thahabi, published in Cairo, Dar Gharib for printing, publishing and distribution, 1990

\section{Structure of the study:}

The introduction includes: the importance of the subject and the reasons for chosen it, the problem, and the hypotheses of the study.

The first topic: What is the res judicata of the criminal judgment?

1. The concept of criminal judgement and its authenticity.

2. the conditions of the res judicata of criminal judgement before the civil judge.

3. The Legal Nature of the Authenticity of res judicata Penal Law.

The second topic: the implications of the of res judicata of the criminal judgment before the civil courts.

1. the direct effects of res judicata of the criminal judgment before the civil judiciary.

2. the indirect effects of res judicata of the criminal judgment before the civil judiciary.

Conclusion: including the most important findings and recommendations. 


\section{What is the criminal judgement:}

8.1. the criminal judgement in language and terminology:

Criminal judgement in Language:

According to Ibn al-Manzoor ,Arabic language has different meanings such as ,reward or recompense. Ib it is said " he rewards him" or in the pray "may god rewards him well" which means god has rewards him. Another meaning is "retribution" as it is used in utterances "I punished him by his fault" which implies penalties also can mean "Justice" when it is related to the day of judgement .In al Manawi dictionary it meant to provide both benefit and harm.

According to Al-Kilani (1995,p15) the punishment is intended to reward the offender for his action, and this is only imagined in evil, and the offender who committed the crime deserves to be punished before the nation and people by a penalty that is appropriate to his action .

Crimminal judgement( penal provisions) in terminology:

Penal provision does not have an independent definition in the books that explained the Code of Criminal Procedure, as is the case with the definition of judicial judgment. Criminal judgement is defined as "The rules of form taken at the time of the crime for the purpose of controlling, investigating, arresting, prosecuting and imposing the judgement against offender, the law shall determine the competent authorities which carry out such proceedings, whether the authority of investigations or judicial." (AL-Kilani,1995).

Another defenition is that "A set of rules and procedures governing a criminal case and the taken procedures from the moment of occurrence of the crime to the time of judgement. And the rights and duties arising from such proceedings whether in terms of the criminal prosecution or the civil claim of the criminal case, or the difficulties of enforcement of punishment."(A1 Baher, 2007 ,p10) .

Accordingly, how the penal provision can be defined? We say that the penal provision is the judicial judgment issued by a competent criminal court, with the aim of the crime, and then investigating the reasons, motives, the detection of the perpetrators, and the extent of their criminal liability.

\subsection{The conditions of res judicata doctrine of criminal judgement before a civil judge}

Res judicata, is a kind of ban that a judgement acquires according to an evidence and in which it cannot accept another evidence to be contrary when the judgement is issued in terms of form or subject as it is taken for truth.

Which indicates that the judgment when issued is considered fair, that includes the will of the real law in the case presented, and it is correct, that corresponds to the legal model of the judgment, and is the result of correct procedures.( Awad, 2003, p. 783).

It also means that the decision is the title of truth, that is, it is true in terms of its procedures and its subject. It consists of two parts; one called the validity of evidence and the other the truth of evidence.(Ahmed,2003,p 923). The criminal proceedings are important and expeditious in the investigation and prosecution to satisfy the feelings of the people, to reassure the public opinion that highlight the occurrence of crime, to achieve deterrence, justice and uncover the truth.

The Jordanian legislator has adopted the legal principle of the authenticity of judgments issued by criminal courts and their effect on judgments issued by civil courts. Article (333) stipulates that:

1) The criminal judgment issued by the criminal court in the merits of the penal lawsuit of the acquittal, non-liability, extinguishment, or the conviction shall have the effect of the sentenced matters before the civil courts in the lawsuits in which no final judgment has been issued related to the perpetration of the crime, its legal description, and its ascription to its perpetrator.

2) The judgment of acquittal shall have this effect whether it was based on the refutation of the accusation or if the evidence is not enough.

3) It shall not have this effect if it was based on that the act is not punishable by law.

The Civil Court shall recognize the verdict of the Criminal Court and its civil consequence such as the decision of award or rejection. Otherwise, the civil court shall decide on the merits of the case in accordance with the provisions of the Civil Code.(Mustafa,1988,p.201).

However, the authenticity of the criminal judgement should satisfy the following conditions:

- A judgment is issued by the criminal court about the public right before the dismissal of the personal proceedings before the civil courts. Decisions issued by the investigation authorities are not authentic. 
In the case of a claim of personal right and the judiciary, the civil court shall not be entitled to compensation for damage or non-infringement.

- The final judgment should be issued by the criminal court during the civil court hearing in the personal right case, i.e., the civil action is still pending before the civil court without a final judgment being issued.

- The penal judgment shall be final and not appealable , and the preliminary provisions accepting the appeal are subject to change and are only valid after exhaustion of the methods of appeal and acquittal of the power of res judicata. Preliminary or preparatory provisions have no effect before the civil courts. (Penalty Discrimination No. (79/955), Journal of Lawyers Third Year, p. 33).

If the penal provision of non-responsibility is since the law does not punish the act attributed to the accused, this provision shall not be an argument before the civil court, and it does not prevent it from awarding compensation.

- The civil court has not issued a final judgement in a personal claim, if the judiciary has issued a judgement in this case, the civil judgment acquires its authenticity, even if it contradicts the provisions of the criminal judgment .(Mustafa,1988,p.202).

The case unified the criminal and civil proceedings, because the personal action is not related to the general right of the case and if the difference between the two claims is not authoritative for the criminal judgment of the civil case in this case (Jokhdar 2008, p. 206).

- That what the penal provision has adjudicated shall be necessary, such as proving the crime, its legal adaptation and its connection to the accused. If the criminal judgment decides to convict a person of the crime of mistrust, the civil court shall not consider the incident a theft. Unnecessary matters that are closely related to the harm or non-occurrence of the damage, shall not have effect on the adaptation of the offense .(Al-Kilani,1995,p 490).

The judgment of the criminal court about the general right to the crime committed is an argument before the civil court in relation to what has been decided only in the common dispute between the public and civil proceedings.(Saeed,1998,p.223)

Based on Article (456) of the Egyptian Code of Criminal Procedure The acquittal shall be the same whether it is based on the absence of guilt or insufficient evidence, and it shall not have such force if it indicates that the act is not punishable by law. Thus, the penal provision has its effect and strength in the matters which the criminal court determines according to its jurisdiction, namely the occurrence of the crime, its legal description and its proportion to a particular offender (Al-Kilani, 1995, P. 492).

The Jordanian Court of Cassation and the Penalties No. 9/67 of 1967, p. 796 provided that "if the criminal judgement decided that a person is irresponsible for the charge of negligence that caused the theft of a sum of money, this criminal judgment denies the occurrence of the error to the person in question. Accordingly, all the civil liabilities are precluded and his sponsor will also not be liable .

Then it contradicted this decision by another provision where the Penalties No. (137/72) of 1972, p. 717 stated that if the penal provision hand down the irresponsibility of the defendant for the accident and the abuse because he was not negligent ,this does not affect the right of the victim to return to compensation for damage.

According to Al-Kilani (1995) the acquittal means the absence of civil liability that may arise from the harmful act and that the defendant was not the culprit.

Based on Penalties No. (3/71) of 1971, p. 182 , the penal provisions which are related to the civil courts are the final decisions of the courts of the public prosecution, where the decisions of the prosecutor in the investigative proceedings have no effect on the civil proceedings .

The judgment of acquittal issued by the criminal court shall be authoritative before the civil court, whether it is the basis of the absence of the charge or insufficient evidence in accord to the opinion that the civil judge decision is related to the acquittal issued by the criminal court.Unless the acquittal or the incident attributed to the accused is not originally valid and has not been obtained. Or that the accused person is not the culprit, but if the acquittal is not proven or suspected, there is no effect of this provision and it is not linked to the civil judge (Penalties No. (119/72) of 1973, p. 806).

\subsection{The legal nature of res judicata of criminal judgement}

Several theories have emerged in determining the legal nature of the res judicata of criminal judgment. Two theories emerged in determining the basis for the principle of res judicata doctrine: the theory of the legal context 
and the theory of substantive legal rule. Therefore, we will present its legal basis as follows:

\section{A.The theory of legal presumption}

Paragraph (1) of Article (41) of the Jordanian Evidence Law No. (16) for the year 2005 stated that "1.The provisions that have final decision shall be considered a legal argument for the taken decision. An evidence may be accepted that contradicts this presumption, but such provisions shall have no power except in a dispute between the opponents themselves without changing their characteristics.2. The court may take this presumption". The Jordanian legislator considered in the previous text the authority of the judgement in which it is judged to be a non-conclusive legal presumption, where it may be revoked by another evidence ${ }^{1}$ Al-Zawahra ,2012., P. 47).

Article (405) of the Egyptian Civil Code (Abrogation) stipulates that "the provisions that have obtained the power of the ruling order shall be an argument in the manner in which the rights have been set forth, and it is inadmissible to accept a proof that contradicts this " Article (406) of the Evidence Section states that "a civil judge shall not be bound by a criminal judgement except in the facts in which this judgment was adjudicated and his adjudication was necessary"

The legislator assumed an irrefutable assumption that the provision is the title of truth and authenticity, despite its impurities, and that, in accordance with the ancient Roman rule, by matching the judicial truth with the truth, the judicial truth may deviate - in rare cases - from the truth, The majority of the cases are the same, so we say that the presumption is most likely to fall into the same category as any other legal presumption ( Ramses ,1968 ,p 576).

It is taken on this theory that the argument that the legal or absolute legal argument does not accept the proof of the contrary which means it is never refuted, the conclusive legal presumption is no more than a basis of evidence, even conclusive evidence is not difficult to be refuted by affidavits and swearing as long as the legislator wanted to keep it within the rules of evidence. (Abdel Rahim (1968),p ,315).

The presumption as a rule of proof is the primary purpose of which is to reach the truth, and therefore the opponent has the right to revoke the evidence contrary, and this is required by the nature of the presumption ( Ramses ,1968,p 576).

The presumption in this sense is a weapon that the legislator places in the hands of one of the litigants, who pays the burden of proof, but the other opponent can remove this weapon from his opponent's hand by proving the opposite of that presumption Omar, N, I, (1986) .

Therefore, some jurisprudence goes to the conclusion that the legal evidence is two types: one is related to public order as the basis of the "The child is to be attributed to the bed " basis, and the presumption of conformity with the judicial reality or the force of res judicata. This kind of conclusive evidence does not accept proof of the contrary by any means of proof.

The second type is not related to the debtor's acquittal, that benefited from the creditor's delivery of the deed of debt and the debt of the borrower on which the short-term debts were established. This type does not accept the proof of the contrary unless through questioning the party who the presumption is in his favor by obtaining his recognition or his affidavits.

It is not permissible to prove the opposite of one of these two things, which is contrary to the court for which it made these evidence conclusive, since the recognition of the person who the presumption was in his favor or by breaking his oath indicates unequivocally that the decision which was taken by the legislator in general and based on this presumption does not corresponds to the reality in this individual case and therefore not to be taken into account Saif,1984,p.12).

B.The objective theory

Modern jurisprudence tends to regard res judicata as an objective rule and not as a legal presumption. There are objective rules that the legislator constructs in most cases and turns them into fixed facts, such as legal evidence (Rabeea, E (1992).

Despite the recent jurisprudence that the validity of judicial judgment is not based on a legal presumption but on an objective legal basis, modern techniques have considered it as a legal presumption that the provision is the title of truth (Sanhoury, A (1956).

The provisions of Article (405) of the Egyptian Civil Code, which were transferred from the Civil Code to the Evidence Law, stipulate that "the verdicts obtained by the force of res judicata are justified by the interpretation of the rights, and no evidence against this presumption shall be accepted."

Senhoury (1956,p.333) mentioned that ,what is similar between the objective rule and the legal presumption is that both of them are based on the prevailing majority or the idea of the most likely to occur .The differences 
between the objective rules and the legal presumption is that the objective rule is characterized by taking the idea of the most likely to occur, so it does not have room to appear , and no one has the right to question the legislator about the reasons that led to the establishment of this rule, the idea of most likely occurring is considered the cause of the objective rule, when a rule is determined, the cause disappeared and has no room to appear. While in the legal presumption the idea of the most likely to become remains prominent in it because it is the subject of the presumption, so its effect does not dissolve.

The second advantage of the objective rule over the legal context is its inability to prove the opposite, that is, it must be applied in all cases, regardless of whether the cause is identical to occur. For example, it is impossible to prove that a person who has attained the age of 18 years has not reached the age of maturity, and vice versa. If he is not of that age, he is a minor under the law, no matter how intelligent he is.

On the other hand, the legal presumption may be proved to be contrary. The lessor can prove that, although he has taken the subsequent payment, but the previous payment has not been taken, thereby destroying the presumption of satisfaction with the previous payment. It is not true that every legal presumption accepts the negation by the contrary evidence. It is from the legal evidence that the legislator has made some of the legal presumption conclusive and cannot be proven contrary. If one year passed, it is considered a conclusive legal presumption of the decisions that the provisions have made.

Article (41) of the Jordanian Evidence Law, where the legislator has taken the statute of limitations as a guarantee of the fulfillment of these rights, but this presumption always remains a rule of proof or is an exemption from proof. This means that the opponent who has determined this presumption in his favor can withdraw it by express or implicit approval, and that if he broke his oath about the right directed by his opponent, the evidence terminated, although it is conclusive, and then all the conclusive evidence can be refuted by recognition or oath .

In short, the res judicata is, in our opinion, an objective rule and not a legal presumption. However, if we decide that the basis of the authoritative is an objective rule, what is the reason for this assumption?

Therefore, we cannot consider the unity of the litigants , the subject and the reason the basis of the legality of res judicata of criminal judgement before the civil courts. The civil and criminal proceedings are different in terms of litigants because the litigants in the criminal case is the Public Prosecution and it is not the same in the civil case. The subject of the criminal case is the demand for punishment while in the civil action it is claim compensation. Also, the cause of the criminal action is the commission of a crime while in the civil action is to commit a harmful act ( Senhoury,1964,p.121).

Actually, The criminal legislator has made the criminal judgments an absolute trust, so that their respect for their protection and strength cannot be reconsidered (Abu Al-Wafa, Ahmed (1983) and the penal provision of the civil judiciary is restricted to two considerations: legal and practical; the legal consideration is that the penal provision is an argument against all, But the practical consideration is that the violation of civil law by the civil judge harms the public feeling. People believe in the acquittal of the accused or the conviction of the accused, and then the civil judiciary returns to the contrary, through judging him to compensation or denying the commission by a person who was convicted by the criminal court (Senhoury, 1964, Pp. 1071-1072).

As stated in another provisio Egyptian civil appeal on 24/1/1967 in 18 BC, p. 169 n of that "the criminal judgment must have its authenticity before the civil courts in the case which its basis is the same action of the case subject was issued, so that civil law may not be brought against the criminal judgment, it is unacceptable in the social system that the Criminal Court issue a penal against a person for a crime he committed and on the other hand the civil court concludes that the crime is not committed by that person, whereas the legislator has discussed the proceedings before the criminal courts with regard to the lives, freedoms and guarantees of the people. Once the conviction has been issued, it will absolutely be trusted by all people and in any case, it is not valid to reconsider its subject " (civil revocation dated 14/1/1944,Senhuri,1964).

\section{The effects of res judicata of criminal judgement before Civil judiciary}

The prevention of civil courts from re-examining the content of the penal provision is the essence of the principle of res judicata and the most important consequences that are associated with it. It has an important and essential procedural rule, namely, the rule of criminality that makes sense or stops the civil, both are direct effects of the rule of authenticity "res judicata", which can be explained as follows:

a) It inadmissible to consider the issue of criminal judgment again before the Civil Court. 
The bar to investigate the issue of penal judgment again before the civil court is known as the negative aspect of the res judicata, since it is forbidden to examine the subject again before the courts to explain the meaning of this rule in the Egyptian Court of Cassation, In accord with the Revocation of the Egyptian Civil Date 23/5/1963 we find that "The judgment in the criminal articles shall have its authenticity in the civil case before the civil courts if it is common between the two courts. The courts held that the civil court is bound by a judgment issued in a criminal case but only in relation to the matters decided in the criminal judgment that are common to both the criminal and civil proceedings, the legal description of the act and it can be attributed to the perpetrator. So as not to be contrary to the previous criminal rule .

Among the applications of this rule in the jurisdiction of the Jordanian Court of Cassation we find the following:

1. It is inadmissible to re-examine the driver's liability before the civil court after the criminal court has ruled by a final penalty:

The Jordanian Court of Cassation ruled that (if the second defendant pleaded before the Magistrate's Court that he hit the child Sami and cause him harm, and he also pleaded guilty to an offense of violating the Traffic Law of sudden deviation which means, in accordance with the provisions of Article (332) of the Criminal Code, Has become authoritative and may not be relitigated by the civil courts.

The Court of Cassation ruled that, "If the appellant pleaded that the contribution of his fault in the accident is one-third and the second vehicle is two-thirds, which is also the decision of the experts to determine their approval by the court, the defendant and his insured company are responsible for paying one-third of the damages and the other third shall bear the remaining two thirds. And it became clear that the responsibility of the accident is shared between the two parties, which became the title of the truth in the penal judgement.

This penal provision is an argument that has been issued and it is barred to prove the contrary. It is binding on the civil judge in terms of the principle of the plaintiff liability for the accident jointly with the other driver. The liability of the plaintiff for the accident may be investigated only in relation to the proportion of his involvement in this liability to cover the damage caused by the accident which contributed to the occurrence and the amount of error rate only, and since the report of experience adopted by the courts of the subject has made it clear that the proportion of the plaintiff's contribution to his error in the incident is a third, so he is responsible first ,then insurance company which he insured his car in is liable to ensure a third of these damages only.( The decision of the Jordanian Court of Cassation in its capacity as Human Rights No. 2094/1998 ).

2. It is inadmissible to re-examine the subject of a complaint to give a check that does not have a balance before the civil court after the criminal court ruled by a final penalty:

The Jordanian Court of Cassation ruled that, "since the Court of Appeal as a court of the subject has concluded that the defendant has signed the check in question after his required data has been filled and he has not signed it blank, the defendant's agent argument that his defendant client has not authorized the plaintiff to fill required data under the claim that the check had been signed blank .

3. It is inadmissible to re-examine the subject of the complaint of credit abuse before the civil court after the criminal court ruled by a final penalty:

In this case, the Jordanian Court of Cassation in its capacity as juridical no. 1948/98ruled that " the penal judgment acquired its final decision has the res judicata before the civil courts to that of occurrence of the crime and its relation to its perpetrator. Therefore, the defendant is not allowed to establish evidence to break the judgment of the penal provision that he betrayed the secretariat with the amount mentioned therein" .

4. It is inadmissible to re-examine the subject of a complaint of forgery before the civil court after the criminal court decided in a final penal judgment.

The Jordanian Court of Cassation judged in its decision No. 1421/2002 that "the criminal judgment is considered an argument in which it is adjudicated, and since the decision of the Court of Appeal determined that there was insufficient evidence of fraud in the procuration given by the plaintiffs in the primal rights case and that it was properly organized and signed by them, so it acquired its final decision, so it is not permissible to repeat and say that there was fraud in the procuration subject to the appeal or that some of the plaintiffs in the case did not signed it contrary to article (332) of the Code of Criminal Procedure.

It follows that it is not permissible to re-examine the subject of the judgment that the decisive oath may not be directed at what has been proven to. The Jordanian Court of Cassation stated that "if the penal judgment acquires 
its final judgement of acquitted it becomes an argument against all. Which leads to the decisive oath of the defendants on the incorrect claim of the plaintiff of receiving her golden jewelry, it is unacceptable after it has been established by virtue of their acquittal of the commission of the offense, so that the acquittal was based on the firm conviction that the defendants did not commit the offense assigned to them, which is therefore an argument before the civil judiciary

Accordingly, the decisive oath to them becomes ineffective and illegal (the decision of Jordanian Court of Cassation no. 688/1991).but if the public prosecutor sues a claim to the public right, the plaintiff may transfer his claim to the criminal court, unless the civil judiciary was dismissed by virtue of the basis.

While the Syrian Court of Cassation declared in the judicial rule No. (137) of the Civil Code of 2002 - the first section, as follows:

"Peremptory judicial decisions have absolute authority so that this authority may not be prejudiced in any way. The peremptory judicial ruling prevents the litigants in the case in which it was decided to return to the discussion of the matter that had been dismissed and with new evidence."

The judgement of the Syrian Court of Cassation in the case No. (39), the basis of (609) dated 14/4/1993, stated that: the cassation records infringing on the validity of the argument is infringing on the provisions of the law and must respect the validity of the judgments and or it is considered a serious professional error.

There are other effects of the authoritative effect of the law. For example, the effects are proven to be authoritative in relation to the driver's liability, whereas the liability of the owner is established by law according to the liability of the driver and the authoritative proven by law and beyond the driver to the insurance company. It is proven whether by proven its liability or the unreliability when liability is proven, we find that the Jordanian Court of Cassation decided in its decision No. 142/981 that "the penalty judgement contained in two thirds, the car offense of causing death is an argument accordingly the car owner is obliged to compensate for the damage caused by the accident in interdependence and solidarity. with the driver to whom it operates by virtue of its legal responsibility ".

As well as the denial of responsibility. The Jordanian Court of Cassation decided in its decision No.542/2007 that "if the criminal judgment provides that the defendant did not commit a mistake or a violation of the law, caused or contributed to the occurrence of the accident and ruled that they are not liability, then this provision is an argument against what was dismissed and therefore the insurance company that secured his car shall not be liable for compensation for alleged damages ".

\section{The application of the rule "Penalty Curbs Right" as an effect of res judicata of criminal judgement before the civil judge}

Of the consequences of res judicata of criminal judgement before the civil judiciary is the rule of "penalty curbs right" which means the suspension of the civil case pending a decision on the criminal case associated with it in order to prevent the issuance of a final judgment in the civil action pending a decision on the criminal case.

The Jordanian legislator confirmed that in Article (6)of the Jordanian Code of Criminal Procedure, which states that: "The personal right lawsuit might be instituted following the common right lawsuit before the judicial authority where this lawsuit is instituted, and it might be instituted separately before the civil judiciary. In this case, looking into this lawsuit shall be suspended until the issuance of a final judgment regarding the common right lawsuit."

Article (6) of the Syrian Code of Criminal Procedure stipulates that:

1. The personal right lawsuit might be instituted following the common right lawsuit before the judicial authority where this lawsuit is instituted, and it might be instituted separately before the civil judiciary. In this case, looking into this lawsuit shall be suspended until the issuance of a final judgment regarding the common right lawsuit

2. If the Personal Prosecutor has filed his case with the civil judiciary, it is not warranted to waive it and establish it at the Criminal Court.

Considering this, if the civil action is brought before the civil court to claim compensation, then case of the public right is brought before the Public Prosecution and the civil authority is transferred to the criminal court. The civil judge shall cease to adjudicate the civil proceedings unless they have been dismissed by virtue of the law because he is obliged to abide by the facts decided by the criminal justice system, this is the reason for 
stopping the dismissal of the civil action before the judiciary pending the decision of the criminal court.

The conditions of the application of the rule "Penalty Curbs Right"

That the public action has been sued before the civil action before the civil court or while it is being conducted. For example, a plaintiff files his case before the civil court to request an amount based on a debt bond. The defendant then sues the court to falsify that bond and resort to the criminal court, in such a case, the civil judge shall cease to adjudicate in the civil proceedings until the criminal court decides on the issue of forgery by a final judgment.

This rule is the logical consequence of the power of criminal judgment before a civil judge.

In one case, the Jordanian Court of Excellence ruled in its decision No.274/2000 that: the subject of this lawsuit is the plaintiff's claim to pay the expenses of treatment and residence of his wife in the hospital that return to the plaintiff, and where the subject of the criminal case filed by the defendant was the offense caused by the plaintiff in the original case and others and for his wife death as a result of the urgency of the cesarean section and take her out of the hospital despite her poor health, suffering from high temperature and conducting several operations. This was the reason and the criminal error that led to the death of his wife and it is the focus of the criminal case before dropping it in the general amnesty, where the dismissal of the personal right lawsuit on the basis of proven error in treatment and care and proved the participation of the plaintiff in the responsibility of tort, which led to the death of his wife. Which has authoritative argument related to the subject of the current case.

Where the judgment on the merits of the original case depends on the outcome of the final judgment on the subject of the personal right pending against the hospital and the doctor and before the criminal court, if it is proved that the culprit did not fulfil her agreement according to contract and medical assets in terms of nonentitlement to the amount claimed or to fulfil its obligation to implement flawless with the amount claimed.

Based on the above, the suspension of the judgment on the subject of the case depends and is related to the dismissal of the subject of the personal right of the criminal court in accordance with the criminal case that was dropped for inclusion in the provisions of the general amnesty law, which should be suspended until the verdict in the personal right case in accordance with the provisions of Article (122) of the law Civil Procedure, which indicates the close link between the claim preclusion rule of the civil courts and the criminal rule of civil law.

In a decision of the Syrian Court of Cassation No.623/2006, it stated that: "The general rule is that "Penalty Curbs Right" in the courts, but for the purpose of applying this rule, the civil action shall be brought before the civil court and the general case initiated by the criminal court are both of the same origin. So that the civil dispute cannot be settled by refusal or acquiescence until after the verdict in the criminal case. Since the appellant did not produce enough evidence to stand the civil lawsuit filed by the contestants against him by claiming the debt by virtue of a certified deed from the notary public .

According to the decision No.169/1989 : "Penalty Curbs Right" is only applied if the civil prosecution depends on the dismissal of the verdict in the criminal case).

In accord to the judicial rulings, whether under the Jordanian Court of Cassation or the Syrian Court of Cassation, the researcher considers that the judgments issued by both Tribunals confirm that the issue of criminal judgment cannot be heard before civil courts. The civil court is in no way entitled to re-present the dispute the criminal that gained claim preclusion.

While the Syrian Court of Cassation was more decisive in this matter, where it stated that the issue should not be considered even if it is flawed in form or subject matter or in error in the application of the law, which we did not find applicable in the Jordanian courts. In our opinion, we support the Syrian Court of Cassation. because it is not permissible for the civil judge, according to the law, to reconsider the case that acquired the final decision, and therefore not to infringe on the validity of the judgment and the force of res judicata. 


\section{Conclusion:}

1. The crimminal judgement is the judicial judgment issued by a competent criminal court, with the aim of the crime, and then investigating its causes, motives, the detection of the perpetrators, and the extent of their criminal responsibility.

2. Res judicata is a kind of preclusion enjoyed by the judgment, which is considered by virtue of including a presumption does not accept the contrary evidence in terms of issuance and in terms of form and subject matter, it is the title of the truth

3. The legality of res judicata (claim preclusion) should satisfy the following conditions:

A. The judgment of the criminal court about the public right was issued before the dismissal of the personal proceedings before the civil courts.

B. The final judgment should be issued by the criminal court during the civil court hearing in the personal right case, i.e., the civil action is still pending before the civil court without a final judgment being issued.

C. The penal judgment shall be final and not be subject to appeal.

D. The unity of the case in criminal and civil proceedings.

4. Among the most important effects of claim preclusion(res judicata) before the civil judiciary are the following:

- It is inadmissible to consider the issue of penal judgment again before the civil court.

- It is inadmissible to re-examine the subject of a complaint to give a check that does not have a balance before the civil court after the criminal court decided by a final penalty.

- It is inadmissible to re-examine the subject of a credit-claim complaint before a civil court after the criminal court has ruled that it is a final penal sentence.

- It is inadmissible to re-examine the subject of a forgery complaint before a civil court after the criminal court decided that it is a final penal decision.

Recommendations:

After this brief presentation of the subject of the res judicata in the civil case, and presenting its most important effects, the researcher recommends the following:

- The absolute claim preclusion of the criminal judgment is limited to what is specified in the criminal case alone. If the law allows an exception to bring a civil action to the criminal court when it is a criminal case, it does not change the nature of that civil action on the one who was an opposing in it alone.

- It is desirable if the Jordanian legislator approved the Egyptian legislator to consider the res judicata on the basis that it is a legal presumption of law because the ruling is the title of truth, where the Jordanian legislator considered the res judicata to be a conclusive legal presumption so conclusive that it may be revoked by another evidence.

\section{References:}

Abdel Rahim, A, M (1968), New Commercial Civil Procedure Law, 1, Dar Al-Nahda Al Arabiya, Cairo, Egypt. Abu Al-Wafa, A (1983), Evidence in Civil and Commercial Materials, Beirut, University House. Al Baher, M(2007) Principles of Jordanian Criminal Procedure Law, p. 10. Gokhdar,H(2008) Preliminary Investigation in Criminal Procedure, Comparative Study, Dar Al-Thaqafa Publishing House, Amman. Hindi,A(2003) Law of Civil and Commercial Procedures, New University House. Jafar, A, M() Principles of Criminal Trials, II, Dar al-Nahda al-Arabiya, Cairo.

Jokhdar, Preliminary Investigation into Criminal Procedure, Comparative Study, Dar Al-Thaqafa Publishing and Distribution, Amman, 2008, p. 206.

Mark, Soliman (1983), Al-Wafi in explaining the Civil Code, sect. 2, (Harmful Action and Civil Liability), Section I, pp. 119-121.

Mustafa, M,M(1988), Explanation of the Code of Criminal Procedure, Cairo University Press and the university book, the twelfth edition, p. 201.

Omar, N, I(1994), Law of City and Commercial Proceedings, New University Publishing House.

Omar, N, I, (1986), The Origins of Civil Commercial Pleadings, i., Knowledge Establishment, Alexandria, Egypt.

Rabeea, E (1992) Evidence and its Proof in Criminal Evidence between Islamic Law and Positive Law, unpublished doctoral dissertation, Amman, p.385.

Ramses,B (1968), Criminal Proceedings, The Establishment of Knowledge, Alexandria.

Sahah, R, M, \& Fayoumi, al Mesbah al muneer, Al Fayrousbadi, al Muheet dictionary. 
- $\quad$ Saif, R (1984), the mediator in explaining the Civil and Commercial Procedures Law, II, Dar Al-Nahda Al-Arabiya, Cairo

- $\quad$ Sanhoury, A (1964), The Mediator in Explaining the New Civil Code, C1, Sources of Commitment, Cairo,

- Sanhoury, A (1956), the mediator in explaining the new civil law, proof and implications of the obligation, publishing house of the Egyptian universities.

- $\quad$ Saeed,R,O(1998) Explanation of the Penal Code "General Section", p. 223.

- $\quad$ Tango, Samir (1997), General Theory in Evidence, Alexandria, University Press House.

- $\quad$ Zawahra, A, Y(2012) The Legitimacy of Penal Law, op. Cit., P. 47.

- $\quad$ Zuabi, A (2003) Civil Procedure, Part II, Wael Publishing House. 